\title{
Research Design and Data Recovery Plan for Archaeological Site $41 \mathrm{GM} 23$
}

Follow this and additional works at: https://scholarworks.sfasu.edu/ita

Part of the American Material Culture Commons, Archaeological Anthropology Commons, Environmental Studies Commons, Other American Studies Commons, Other Arts and Humanities Commons, Other History of Art, Architecture, and Archaeology Commons, and the United States History Commons

Tell us how this article helped you.

This Article is brought to you for free and open access by the Center for Regional Heritage Research at SFA ScholarWorks. It has been accepted for inclusion in Index of Texas Archaeology: Open Access Gray Literature from the Lone Star State by an authorized editor of SFA ScholarWorks. For more information, please contact cdsscholarworks@sfasu.edu. 


\section{Research Design and Data Recovery Plan for Archaeological Site 41GM23}

\section{Licensing Statement}

This is a work produced for the Texas Department of Transportation (TxDOT) by the report producer. TxDOT and the report producer jointly own all rights, title, and interest in and to all intellectual property developed under TXDOT's contract with the report producer. The report may be cited and brief passages from this publication may be reproduced without permission provided that credit is given to both TxDOT and the report producer. Permission to reprint an entire chapter, section, figures or tables must be obtained in advance from either the Supervisor of the Archeological Studies Branch, Environmental Affairs Division, Texas Department of Transportation, 125 East 11th Street, Austin, Texas, 78701 or from the report producer. 
RESEARCH DESIGN AND DATA RECOVERY PLAN FOR

ARCHAEOLOGICAL SITE 41GM23

State Department of Highways and Public Transportation

Austin, Texas

September 1988 


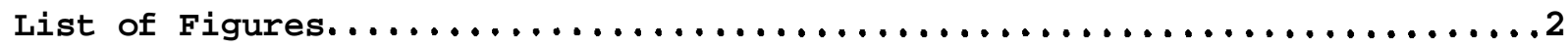

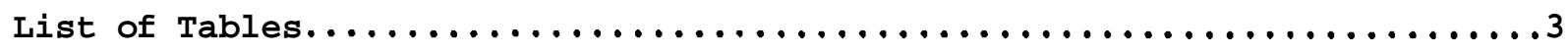

Introduction and Historical Summary $\ldots \ldots \ldots \ldots \ldots \ldots \ldots \ldots \ldots \ldots \ldots$

Site Description. $\ldots \ldots \ldots \ldots \ldots \ldots \ldots \ldots \ldots \ldots \ldots \ldots \ldots \ldots \ldots \ldots \ldots \ldots \ldots$

Summary of Eligibility..................................

Research Domain............................................ 10

Methods...............................................

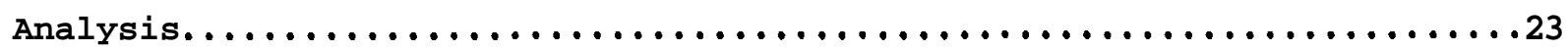

Consultants and special studies...........................25

References Cited...................................26 
Figure 1. Site location map within Grimes County, Texas................

Figure 2. Site map showing location of test units $\ldots \ldots \ldots \ldots \ldots \ldots \ldots \ldots \ldots$

Figure 3. County map of Texas showing the relationship of Grimes County to Prehistoric Texas Cultural Areas ................... 11

Figure 4. Proposed unit placements for further research $\ldots \ldots \ldots \ldots \ldots \ldots \ldots \ldots .20$ 
LIST OF TABLES

Table 1. Subsurface materials recovered from $41 \mathrm{GM} 23 \ldots \ldots \ldots \ldots \ldots \ldots \ldots$ 
RESEARCH DESIGN AND DATA RECOVERY PLAN FOR

ARCHAEOLOGICAL SITE 41GM23

Introduction and Historical Summary

Site 41GM23 was originally located by William M. Sorrow during the Millican Reservoir survey in 1973. Its presence was indicated by the occurrence of flakes and burned rocks. The site was plotted as covering a hill top and extending downslope towards Rocky Creek (Fig. 1). The archaeological site was re-examined in May 1988 during a routine archaeological survey by the-State Department of Highways and Public Transportation for a proposed bridge replacement on County Road 247 in Grimes County. The site was reevaluated and found to contain ceramics and burned rock hearths exposed by recent disturbance. Testing was proposed to determine the depth, age, and significance of that portion of the site within the CR 247 project. Testing was conducted during the week of June 6, 1988 by John W. Clark Jr. with field assistance provided by the SDHPT District 17 office.

Shortly before the reexamination of the site, the bridge over Rocky Creek was removed due to structural defects after which a temporary low water-crossing was built by county maintenance forces. During this construction phase, a bulldozer trench was dug across the site to allow heavy equipment to enter the creek channel. This trench was subsequently filled using topsoil from the proposed 60 feet wide right-of-way. An undetermined amount of soil was removed from the surface of the site. 
This Page Redacted Per THC Policy 
Testing of the site consisted of the excavation of three 1 by 2 meter test units within the proposed right-of-way (Fig. 2). Vertical control was maintained in $20 \mathrm{~cm}$ vertical levels and excavated to $120 \mathrm{~cm}$ in sandy soils. Sterile soils were not reached. Testing was halted once it became apparent that the site contained an intact buried hearth and that there was a quantity of lithic material present in relatively undisturbed contexts.

Archaeological testing of 41GM23 produced a quantity of diagnostic prehistoric materials. These included sand-tempered potsherds, 1 arrowpoint and 4 dart points from subsurface contexts. A sandstone hearth was found in level 2 of Test Unit 2. A preliminary analysis based on a limited artifact sample revealed that the arrowpoint was found in level 2, the sherds are from level 2 and level 4, and the dart points were found in level 1, 2, 3, and 4. There appears to be a slight tendency for dart points to occur below arrowpoints. Table 1 synthesizes the recovered materials.

Table 1: Subsurface materials recovered from 41GM23.

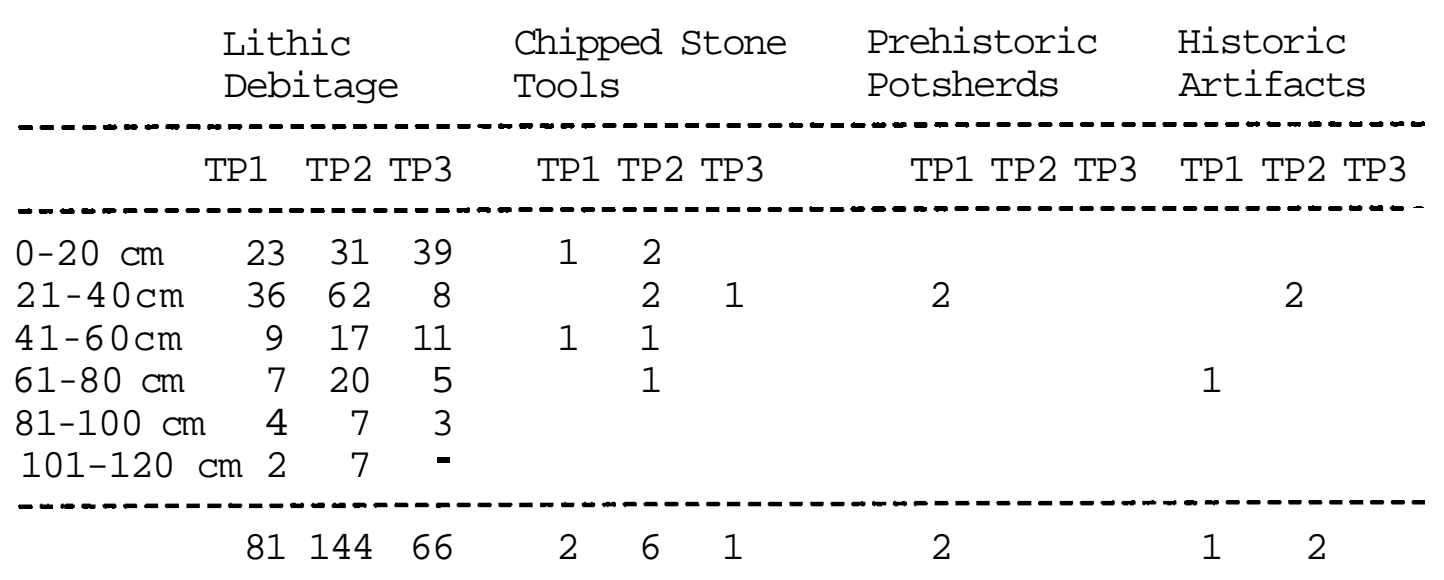

Table 1 indicates that most of the tools and debitage are located in the upper $80 \mathrm{~cm}$ of the site. Flake debitage extended to a minimum depth of $120 \mathrm{~cm}$ although some downward displacements and bioturbation in sandy soils might be 


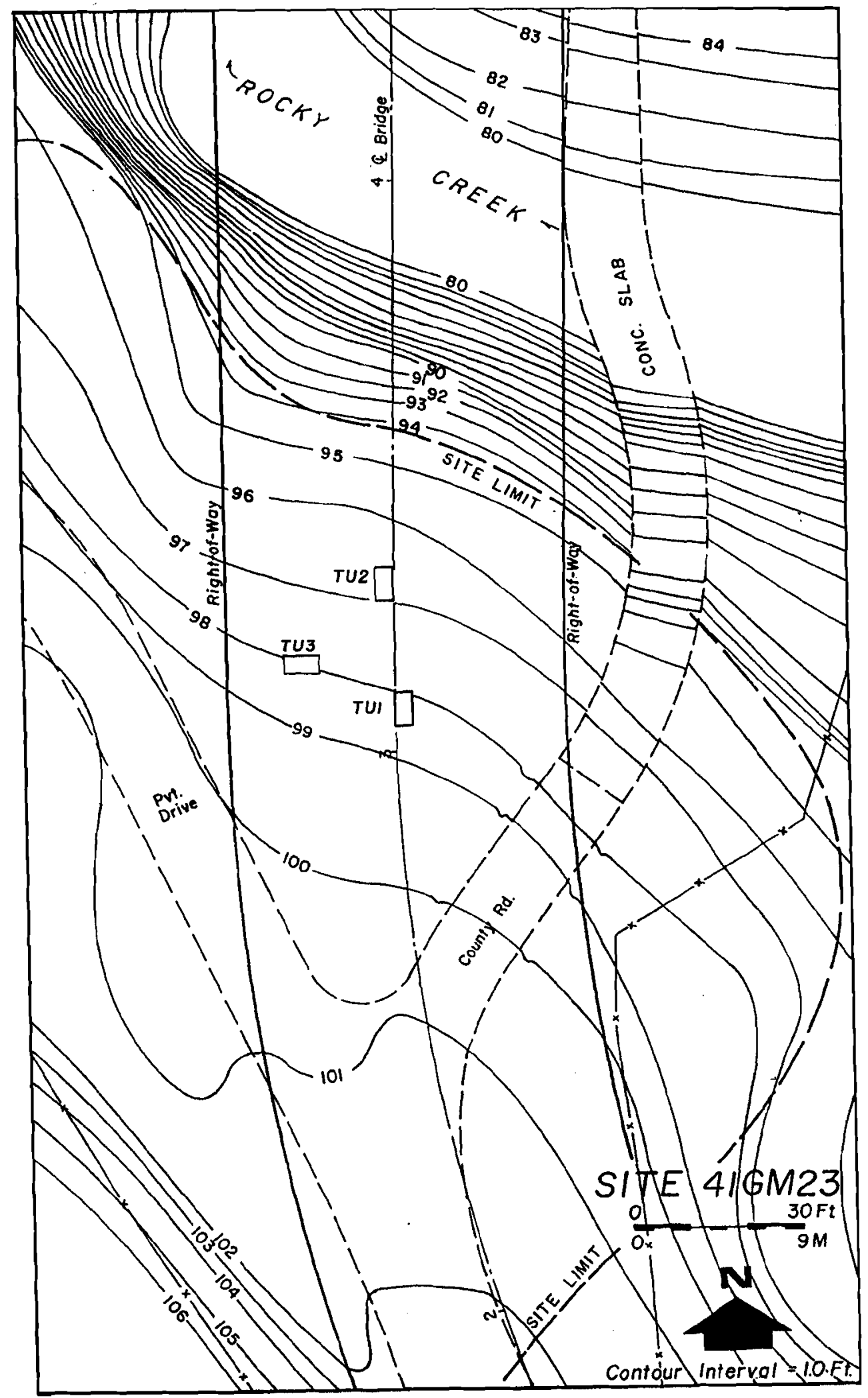

FIGURE 2. Site map showing location of Test Units. 
responsible for this. Site $41 \mathrm{GM} 23$ appears to have sufficient depth for isolating various components which may be present.

\section{Site Description}

The site is situated on the south bank of Rocky Creek about 1.5 miles south of the intersection of County Road 247 and FM 3090 in Grimes County, Texas. This large site is located along a hill top south of the creek with the northernmost limits extending to the creek and within the right-of-way of County Road 247.

The right-of-way consists of a 60 feet wide corridor crossing the northern site limits on a north-south alignment (Fig. 2). Most of the site is located upslope from the project and will not be affected by SDHPT construction activities.

The portion of $41 \mathrm{GM} 23$ within the right-of-way is located along a second terrace system on the south side of Rocky Creek with the present terrace surface about 10 feet higher than the creek channel. Since an undetermined amount of soil has been scraped from the site surface within the right-of-way, the original elevation has been lost. Other impacts on the site include the bulldozing of the trees within the proposed right-of-way and the excavation and refilling of a bulldozer trench in the northwestern part of the right-ofway. The site was the location of a earlier bridge immediately west of the project. Natural impacts include bioturbation by burrowing animals as would be expected in deep sandy soils. 
The principal vegetation on the site consists of giant ragweed, sunflowers, cockleburr, black eyed Susan, baby blue eyes and small hackberry sprouts. Elms and hackberries are found along the county road right-of-way fence as are mustang grapes. A small amount of grass is found on the cleared portion of the site.

A soil survey has not been published for Grimes county. Test excavations indicate that the site contains at least $120 \mathrm{~cm}$ of sandy soil overlying a zoneof dark brown clay which extends to an undetermined depth. The uppermost soil zone intact within the right-of-way is a medium brown sand which overlies a light brown sand over a light tan sand.

The site is situated in the Post Oak Savanna vegetation area defined by Gould (1969: 11). The area consists of rolling hills with acidic light colored sandy loams. Climax grasses in the uplands include little bluestem, Indian grass, purple top, silver bluestem and others. 


\section{Summary of Eligibility}

Based on testing results the State Department of Highways and Public Transportation believes that the deposits in the right-of-way meet the criteria for eligibility for the information it contains (Criterion D, 36 CFR Part 60.4) Broad research topics which may be addressed by the excavation of the site include cultural chronology, definition of the resource base, cultural adaptation and cultural diffusion. The probable presence of early ceramic and late preceramic occupations presents an opportunity to examine remains of a cultural adaptation for these time periods. Use of specialized dating techniques may by applicable if the required resources are encountered.

\section{$\underline{\text { Research Domain }}$}

Grimes County occupies an interesting area in Texas prehistory. The county is located near the western edge of the East Texas cultural area as defined by Story (1977), the northernmost edge of Texas prehistoric coastal influences (Aten 1983), and along the eastern edge of the Cross Timbers Vegetational Zone in an area long called a cultural Transition Zone between Central, coastal, and East Texas (Kelley 1955). Figure 3 plots Grimes County in relation to the suggested prehistoric cultural regions.

The East Texas cultural area represents a distinct archaeological region with a number of distinguishing cultural traits. The Paleo-Indian period and the earlier portions of the Archaic are not well understood due to occurrence of archaeological sites in bioturbated sandy soils. It is generally accepted 


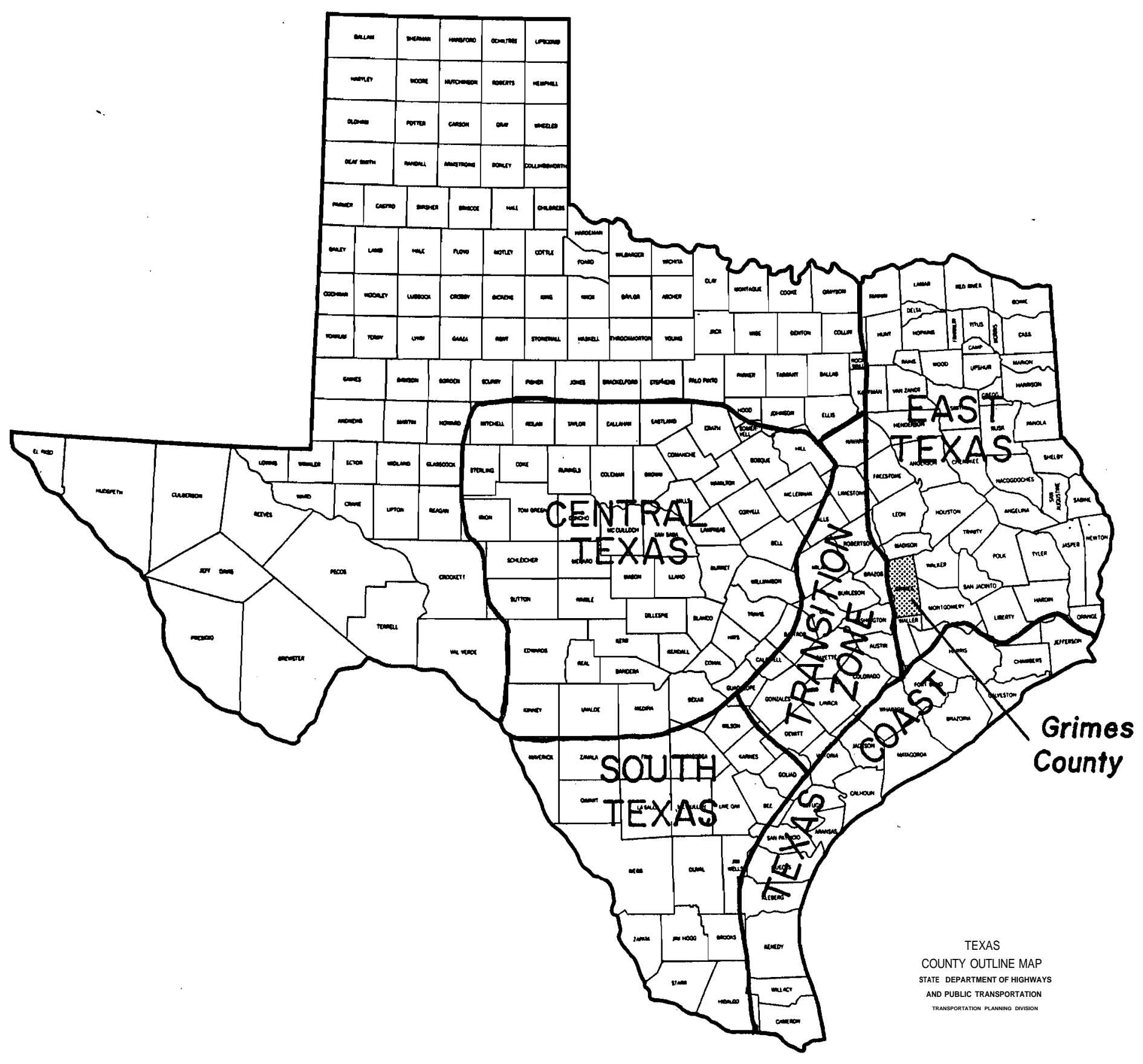

FIGURE 3. County map of Texas showing the relationship of Grimes County to Prehistoric Texas Cultural Areas. 
among archaeologists in the region that the Middle Archaic is distinguished by straight-stemmed Yarbrough dart points and by a series of largely untyped expanding stemmed forms. The Late Archaic and Early Ceramic period is dominated by contracting stemmed Gary dart points which become smaller in ceramic periods. The Early Ceramic period represents a Woodland stage of development with sandy paste pottery appearing well before the advent of arrowpoints. Villages appear in the Late Ceramic period as do arrowpoints. Late ceramics may have grog-tempering. Planned cemeteries with extended burials and grave offerings appear in the Late Ceramic period. Caddoan pottery may be expected in Late Ceramic contexts. A variety of arrowpoint types occur with Perdiz and Alba types being more common in the southern part of East Texas than in the northern half.

The Central Texas archaeological region varies greatly from the East Texas region although they are separated by less than 100 miles. The Central Texas region is also better understood due to excavations in deep terrace sites which allowed stratification of deposits. During the Paleo-Indian period, Central Texas resembles most of the state with occasional finds of Clovis, Folsom, Scottsbluff, Plainview, and ㅌngostura dart point types. The San Patrice, a fairly common early type in East Texas, is rarely found in Central Texas. The Central Texas area becomes a distinct archaeological region by at least 6,000 years B.P. and is characterized by an archaic subsistence base which lasted until European contact. Many dart point types are indigenous to this area and include a series of barbed dart points with ground bases diagnostic of the Early Archaic period. The Middle Archaic period is recognized by parallel stemmed dart points. The Late Archaic period contains several dart point types with expanding stems. Arrowpoints began to appear around 
1400 years ago while pottery was a very recent addition after 1400 A.D. The introduction of ceramics and arrowpoints had little if any impact on the nomadic hunting and gathering subsistence base. Burned rock middens, massive mounded accumulations of burned limestone fragments, are an index of the Middle Archaic period and appear to relate to processing vegetal products. Burials are rare for any time period in Central Texas and cemeteries appear after arrowpoints. Burials are flexed for all time periods and usually without grave offerings. Central Texas projectile point types seldom occur i $\mathrm{n}$ East Texas and East Texas types are even rarer in Central Texas. Ceramics are plain bone-tempered wares. Less than 20 sandy-paste sherds have been reported from Central Texas.

The Transition Zone is a 40-50 mile wide strip of land that correlates with the Texas Cross Timbers Vegetational Zone. The zone was defined by Kelley (1955) as an area where the Central Texas region gradually gave way to East Texas and where traits of both regions occurred. More recent research has suggested that the area may represent a distinct cultural zone which shares some traits of both regions but has a number of diagnostic projectile point types unique to the area (Goode 1984). Paleo-Indian diagnostic artifacts are similar to those found in most of the state with San Patrice points being very rare. The long archaic sequence resembles that of Central Texas although many of the common Central Texas types are missing or occur rarely. At present there is no indication of a Woodland stage of development. Like Central Texas, the archaic sequence continues to European contact and arrowpoints predate ceramics. Arrowpoints are primarily Central Texas types f-Scallornand Perdiz) while ceramics are sandy-paste plain wares similar to East Texas. There does not appear to be a shift towards grog-tempering as in East Texas. 
Archaic cemeteries with grave offerings do occur and show a resemblance to East Texas although the burials are flexed.

The archaeology of the upper Texas coast is very poorly understood for several reasons. A rise in sea level following the last glaciation and an unstable shoreline until the barrier islands formed around 3500 years ago has destroyed or flooded most of the Archaic shoreline sites. There is also a scarcity of lithic resources in the coastal counties and this led to a utilization of worked marine shells and the production of very few diagnostic projectile point types. The lack of projectile points has created serious problems in seriating a long archaic sequence. The ceramic period is better known and is characterized by a sequence of sandy paste pottery types which are sometimes painted or decorated by incising or rim notching. Burials occur as flexed interments within cemeteries during the archaic and ceramic periods and may be accompanied by burial offerings. A nomadic hunting and gathering subsistence pattern was utilized through historic contacts.

Previous archaeological research in Grimes County has consisted of surveys by Sorrow and Cox (1973), Bond (1977), Fletcher (1979), Kotter (1982), Baxter (1982), and Glander (1986). Subsurface testing has been conducted by Ippolito (1979), Davis (1981), and Bond (1981). Recovered artifacts from 41GM68 included sandy paste pottery, indicative of the southern portions of East Texas and the Transition Zone, A Gary dart point typical of East Texas and an Almagre dart point (Ippolito 1979). Testing at 41GM71 yielded two dart points. One Gary and one unidentified dart point were recovered (Ippolito 1979). Testing of 41GM57(Davis 1981) produced sandy paste pottery and Perdiz arrowpoints. Sandy paste pottery occurs in eastern Texas and the Transition 
Zone while Perdiz arrowpoints are commonly found in Central Texas and in the Transition Zone. Site 41GM58 contained materials similar to 41GM57 as well as the remains of at least 2 American Indians.

The meager amount of archaeological data from the county has suggested that the county may have cultural ties to several areas and to the Transition Zone. The four dart points found in controlled excavations include 2 Gary points which are normally considered Late Archaic or Early Ceramic (Woodland) indicators in East Texas. The Almagre specimen is large and crude and may represent a preform. The unidentified specimen cannot be tied to cultural areas or time periods. Arrow points are limited to the Perdiz type, a common form in Central Texas, along the upper Texas Coast, and in the Transition Zone. Sandy paste pottery also occurs along the coast, in East Texas and in the Transition Zone.

Due to the geographic location near the borders of these three cultural areas research efforts on Site 41GM23 should be oriented towards determining the similarities and differences between this site and reported sites in adjacent cultural areas. Such efforts should provide valuable data on cultural affiliations and interactions with the adjacent cultural areas.

The major objectives of mitigation of this site are:

(1) to locate intrasite features and artifacts as a means of possibly determining site function. The frequency and types of features recovered should provide some data on the type of site represented (village site, base camp, hunting camp, special purpose site for extracting a particular resource, cemetery locale). This will provide data for approaching the role of site 
41GM23 within a county-wide and regional settlement pattern and may provide some insight into relationships with adjacent cultural regions. As an example, the location of a cemetery with extended burials or house patterns or pits would suggest affiliations with the East Texas culture area. The types of artifacts recovered should also provide some information on the functions being performed on the site. The presence of grinding tools would suggest vegetal processing, a high occurrence of scrapers would suggest hide working, large numbers of primary decortication flakes would suggest the early stages of lithic reduction on the site, etc. Both the presence and absence of artifact types should provide some data on activities performed or not performed within the excavated parts of Site 41GM23.

(2) to determine which cultural zone most closely resembles Site 41GM23. There are considerable differences in the projectile point types recovered in East Texas, Central Texas and in the Transition Zone. Projectile points should be compared to several sites in each of these areas to determine the degree of similarity. A high degree of similarity to types and frequencies in East Texas would suggest a strong relationship to that area while a high frequency of Central Texas types would imply ties to that cultural region. Ceramics should be compared to those recovered in both eastern Texas and in the Transition Zone with emphasis made on comparisons with sites in the San Jacinto River Basin, Harris County, Fayette County, Burleson County, Limestone, and Freestone Counties. The occurrence of sherds with coastal lip notching or engraving or asphaltum would imply ties to the coastal area and the presence of Caddoan sherds would suggest relationships to East Texas. Efforts should be oriented towards comparing the ceramic assemblage to the Transition Zone to determine the extent of bone-tempered ceramics present in 
that zone and on 41GM23. The vertical distributions of projectiles and sherds from 41GM23 should also be studied to determine cultural ties. Ceramics occur before arrowpoints in East Texas but after arrowpoints on the coast and in Central Texas. Recovered data from 41GM23 should indicate whether pottery is older than arrowpoints and allow inferences to be made about cultural relationships. A similar analysis should be made of "non-diagnostic'' tools to determine if there are as yet undiscovered relationships to a specific cultural area. Features should also be compared using an analysis based on size, shape, and implied functions.

(3) to attempt to develop a cultural chronology and tool typology. There is not an adequate chronology which can be applied to this county. Tool typologies should be developed by a combination of attributes including shape, working area, and edge angle studies. A microscopic edge analysis will be attempted on recovered tools but its utility may be hindered by the poor quality of lithic resources utilized. Low grade quartzites and petrified woods commonly found in the area may not be conducive to wear analysis studies.

(4) to compare the site locality with others in Grimes county and adjacent counties to provide information towards a definition of settlement pattern. The analysis of features and artifacts should provide data suggesting site type and function. An examination of landforms should provide data on environmental ecotones. Comparisons of site type (village, cemetery, hunting campsite, quarry locale, etc.) and age will be made to landforms. When the data from 41GM23 is combined with survey and testing data from other sites within Grimes County a pattern of site type and age is expected to emerge. 
(5) to determine the extent of and damage caused by bioturbation within the site deposits. Due to the deep sands present on the site, gopher activity is expected to have occurred throughout the site's history. The extent of such disturbances needs'to be addressed and efforts made to determine the overall effect of such activity on the site. This analysis can be approached by a vertical analysis of historic artifacts throughout the deposits and by efforts to reconstruct broken tools and artifacts to determine the vertical and horizontal separations. Vertical distributions of ceramics, arrowpoints, and dart points will also be performed. The occurrence of ceramics or arrowpoints with Middle Archaic dart points will suggest some degree of disturbance.

(6) to determine the resource base being exploited. Attempts should be made to determine the source of the lithic materials by computing the frequencies of quartzites, petrified wood, Uvalde gravels, and Central Texas flints being utilized. Quartzites and petrified wood are local lithic resources while the distinctive Uvalde gravels are found within the Transition Zone. Central Texas flints are found along the eastern edge of the Central Texas cultural region and are distinguishable by color and waxiness. Attempts should be made to identify nonlocal flint resources in the collections including novaculites, Frisco chert, Zipper chert, and other resources found in southeast oklahoma and Arkansas. An analysis of cortical surfaces should provide useful data on whether crytocrystalline materials were collected from streams or from outcrops. Some bone was recovered in the testing and additional excavations may provide data on species being exploited and possibly seasonality. Fine screening techniques may also recover microflora and if so efforts should be made to determine where this material was collected by the site inhabitants. 
The floral and faunal assemblage should allow some inferences to be drawn about ecological ecotones being utilized by prehistoric populations.

\section{Methods}

The methods outlined below will enhance data recovery and optimize the potential to address the research problems discussed above.

The portion of 41GM23 to be impacted by the SDHPT measures approximately 30 meters north-south by 20 meters east-west and contains roughly 600 square meters of site. A large portion of this area has been damaged by the construction of a private roadway and county road with accompanying drainage ditches. Approximately 380 square meters of the site are in relatively undisturbed contexts although the upper soil zone has been scraped away by county maintenance activities. The excavation of four blocks of 4 meter squares are proposed for the site (Fig. 4). This will involve the excavation of 64 one meter units and will equate to slightly over $20 \%$ of the less disturbed portions of the site. A $20 \%$ sample of the site in the right-of-way was chosen for excavation and should provide an adequate sample of materials and areas of the site within the project right-ofway without excessive duplication of materials and artifacts. The excavation of 6 square meters of soil during the testing phase resulted in the recovery of 291 flakes, 9 chipped stone tools, 2 prehistoric potsherds, and 3 historic artifacts. The excavation of the proposed 64 square meters should yield approximately 8 times this total and will provide a sample of artifacts large enough to be valid and still small enough for a thorough analysis. The excavation of four 4 meter blocks will allow large excavation areas to be opened and should provide large enough 


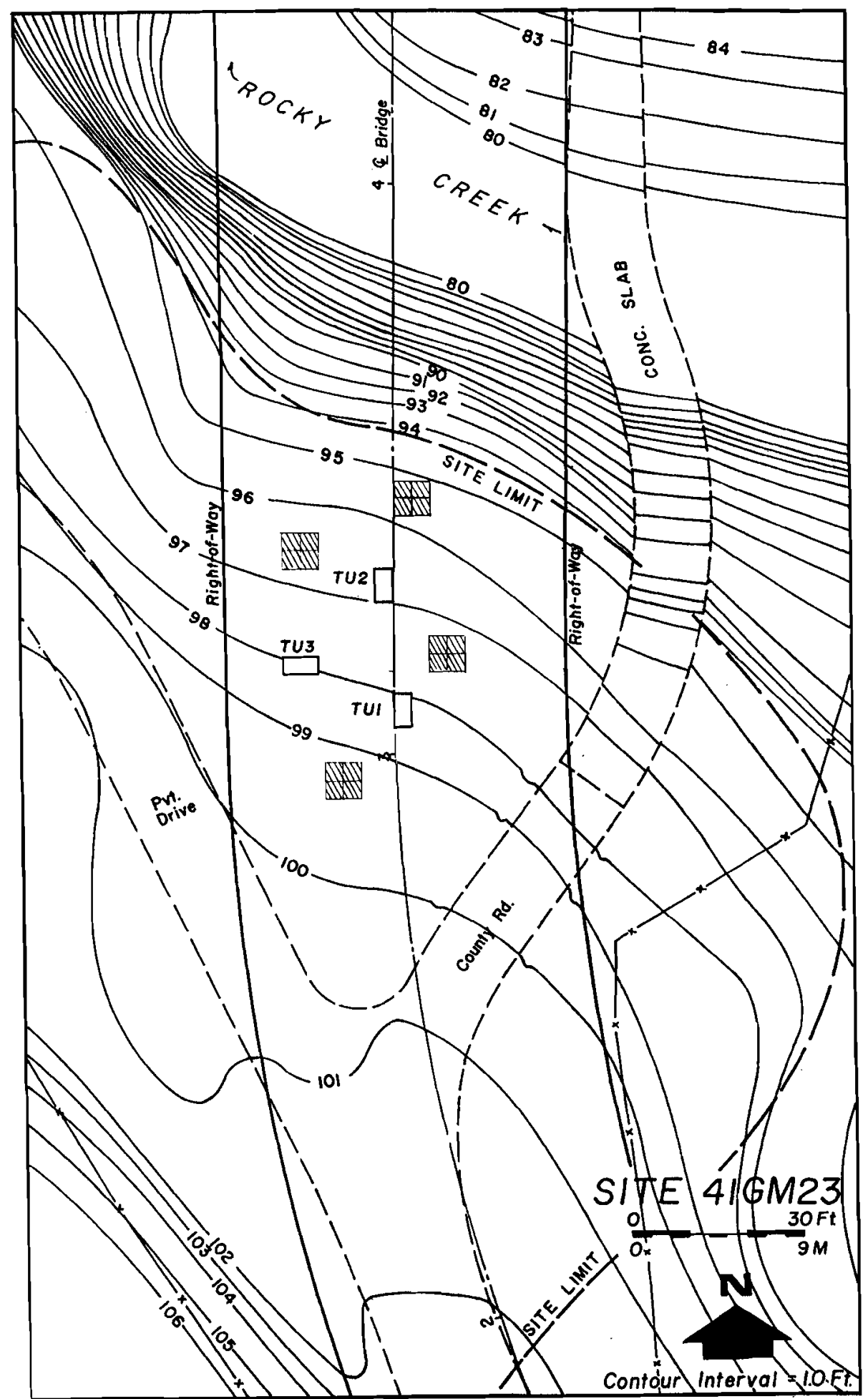

FIGURE 4. Plan map of Site 41GM23 showing test units and suggested locations for additional 16 excavation units, shown crosshatched. 
areal coverage to locate features and detect any living floors or occupation surfaces which may be associated with them.

Due to the sandy nature of the site and the depths involved (a minimum of 120 $\mathrm{cm})$, large excavation blocks are proposed. The use of 4 meter square blocks will be safer in the sandy soils, will be wide enough to prevent dangers involved with slumping of deposits, and will be wide enough to allow excavation at considerable depths. The use of contiguous units will also facilitate locating features and determining the extent and effect of bioturbation within the deposits.

Actual unit placement will be left to the discretion of the field excavators. It is suggested that the block be located approximately in the areas shown in Figure 4. This pattern will allow some spacing between the units and also allow areas north, south, east, and west of the Test Units to be explored more thoroughly. It will also allow comparisons of occupation materials near the creek to be made to areas farther from the watersource to determine if there are differences in site activities within a small area.

The site will be gridded on magnetic north and units will be labeled by their south and east coordinates. The grid will involve 1 meter squares which will be excavated in $10 \mathrm{~cm}$ deep vertical levels. The 16 one meter squares within a block will be excavated in a manner where all units are taken to a depth of 10 cm before any deeper levels are excavated. This procedure will strip the site in $10 \mathrm{~cm}$ deep increments and allow greater chances of locating occupational surfaces in place. 
Records will be kept for each level and unit. Soils will be screened through 0.25 inch or smaller mesh hardware cloth, with materials bagged appropriately. Isolatable associated surfaces or contextual associations will be excavated using finer techniques. Surfaces will be troweled with tools piece-plotted, when possible and appropriate. Care will be taken to isolate the occupation zones from the other fill. This will maximize potential for identification of activity areas (horizontally) and episodes of occupation (vertically) . All feature matrix fill will be water-screened through 1/16 in. mesh, except for constant volume samples to be taken from each feature, as well as a consistent area from designated 1 by 1 m units. This will maximize the potential for recovery of macrofauna, flora, and smaller lithic debitage. The constant volume sample from each feature will be analyzed by specialists for pollen, organic material and soil constituents, as well as artifacts. Processing the constant volume sample from designated 1 by $1 \mathrm{~m}$ squares will include water screening one half through $1 / 16$ in mesh; the other half, equal in volume to the feature sample, will be processed in the same manner as the constant volume feature fill. The budget should indicate that 5 initial samples will be processed to evaluate the effectiveness of the procedure; if there are negative results, further routine processing will not occur. In all instances, samples will be collected.

A scaled topographic map will be made of the site indicating all disturbed areas, the site grid, features, and elevations. Profiles of the exterior walls of each block will be made in addition to profiles of features. Immediately following the field period there will be a post field conference between the contractor, SHPO, SDHPT, and FHWA to discuss the success of the excavation and the needs for any additional research on the site. 


\section{$\underline{\text { Analysis }}$}

The analysis of materials will be multistaged. Site materials will be processed and prepared for analysis; special samples will be packaged and sent to appropriate laboratories. In order to identify various flint knapping strategies, a lithic reduction model will be developed for each component of the site. The model, once developed, will aid in determining site function. For example, a large portion of small, lipped flakes along with worn, finished tools would indicate tool resharpening behavior. On the other hand a high proportion of primary and secondary decortication flakes with many cores and thick, crude bifaces indicates early stages of lithic reduction.

In addition, different flint knapping behaviors could indicate cultural markers which would help in establishing external relationships at the site. For example, heat treating occurring in a particular stage of the reduction process, the utilization of multi-purpose blanks or preforms, and other subtle traits of the artifacts of each component may be similar to behaviors more typical of sites to the east, west, or south.

The spatial organization of the site, with associated artifacts, may provide the information necessary for discussion of in situ cultural development and contrast with extraregional cultures. For example, a hamlet/village site organization with house patterns, external trash pits, and patterned cemeteries would suggest cultural ties to East Texas. Conversely, if the site appears to be an ephemeral campsite, with scattered hearths at different depths and few other features, then the site may be affiliated with any of the surrounding cultural areas. 
The site data will then be viewed in light of regional concerns. An attempt will be made to define the sites position within the regional culture area. It is possible that the area contained numerous small bands that interacted at varying levels through time with one another as well as with neighboring cultures. Some evidence of this may be observed within the artifact record; it is unlikely however, that definitive statements may be made from the present data. At this level of analysis the researcher must go beyond the individual site level and address problems of a larger spatial area, or region.

A report of data recovery efforts in draft and final form will be submitted for SHPO comment. 


\section{Consultants and Special Studies}

Geology

Faunal analysis

C-14

Lithics

Botanical analysis consultant services will be obtained

Dr. Gentry Steele, Texas A\&M University

Beta Analytic of Coral

Gables, Florida

Research laboratory of

contracting agency Flotation and

Research laboratory of

contracting agency 


\section{$\underline{\text { References Cited }}$}

Aten, Lawrence E.

1983 Indians of the Upper Texas Coast. Academic Press. New York.

Baxter, Ed

1982 Cultural Resource Monitoring: Sedimentation Ponds 9A, 10A, 12A, 13A, and 15, Gibbons Creek Lignite Mine. Espey, Huston and Associates, Document 82330. Austin.

Bond, Clell, L

1977 An Archaeological Assessment of the Gibbons Creek Steam Electric Substation. Texas A\&M University Anthropology Lab, Report 36. College Station.

1981 Testing of Three Archeological Sites: TCMA Gibbons Creek Project, Grimes County, Texas. Texas A\&M University Cultural Resources Laboratory, Report 15. College Station.

Davis, Michael

1981 Archaeological Testing, 41GM57, 41GM58, and 41GM83, TMPA Gibbons Creek Project. Espey, Huston and Associates. Document 81470.

Fletcher, Charles S.

1979 Gibbons Creek Lignite Project: Survey and Appraisal of Cultural Resources in the First Five Year Mining Area. Texas A\&M University Research Foundation, Report 3. College Station. 
Goode, Glenn T.

1984 Archaeological Testing and Recommendations For The Kennedy Bluffs Site, 41BP19, In Bastrop County, Texas. Texas State Department of Highways and Public Transportation Highway Design Division.

Gould, F.W.

1969 Texas Plants: A Checklist and Ecological Summary. Texas A\&M University M.P.-585. College Station.

Ippolito, J.

1979 Gibbons Creek Lignite Project: Vol. II. The Gibbons Creek Steam Electric Station Project: An Archaeological Test and Survey Supplement. Texas A\&M University, Research Report 47. College Station.

Johnson, LeRoy Jr.

1962 The Yarborough and Miller Sites of Northeastern Texas, with a Preliminary Definition of the La Harpe Aspect. Bulletin of the Texas Archaeological Society 32:141-284.

Kelley, J. Charles

1955 The Archaic Culture in Central, Southern, and Western Texas. Paper presented at the 1955 Archaic Conferences, Indiana University. Bloomington .

Kotter, Steven

1982 A Preliminary Assessment of the Cultural Resources within the 
Millican Project, Navasota River Basin, Brazos, Grimes, Leon, Madison, and Robertson Counties, Texas. Prewitt and Associates, Reports of Investigations 19. Austin.

Sorrow, William M. and Wayne N. Cox

1973 Archeological and Historical Resources of the Navasota River Basin, Texas. University of Texas. Texas Archeological Survey, Research Report 26. Austin. 